\title{
Community-based Curriculum in
}

\section{Psychiatric Nursing Science}

$S$ Arunachallam

M. Cur

Post-graduate student

Department of Nursing Science

Rand Afrikaans University

AC Botes

D. Cur

Professor

Department of Nursing Science

Rand Afrikaans University

\section{A Gmeiner}

D. Cur

Senior Lecturer

Department of Nursing Science

Rand Afrikaans University

\section{"Current and future changes within the health care system require reformation in the education and development of professional nurses."}

\section{Abstroct}

As community-based health care delivery is now a prominent feature of the nealth care system in South Africa, nursing curricula are being challenged to prepare student nurses for communitybased nursing roles and responsibilities.

The purpose of this study was to describe guidelines for a community-based curriculum in psychiatric nursing science for a nursing college in KwaZulu-Natal. A qualitative, quantitative, exploratory, descriptive and contextual design was employed. To reach the purpose of the study, a situational analysis was done in three phases to identify the principles for a community-based curriculum for psychiatric nursing science.

Phase I: A document analysis of relevant government policies and legislation. Phase II: Statistics from psychiatric hospitals and community psychiatric clinics. Phase III: Focus group interviews with nurse educators and literature control and conceptual framework

The principles obtained from the three phases were used to formulate the guidelines for a community-based curriculum in psychiatric nursing science (Phase IV). Eight guidelines with practical implications are described for the implementation of a Community-based curriculum in Psychiatric Nursing Science.

\section{Introduction and Problem Statement}

Current and future changes within the health care system require reformation in the education and development of professional nurses. As communitybased health care delivery becomes an increasingly prominent feature of the health care system, nursing curricula are being challenged to prepare student nurses for community-based nursing roles and responsibilities in an everchanging health care environment (Bellack, 1998:99). The move to a com-

\section{Opsomming}

Aangesien gemeenskapsgebaseerde gesondheidslewering nou 'n prominente deel van die gesondheidsorgsisteem in Suid-Afrika uitmaak, word die verpleegkundige kurrikula gekonfrontreer met die taak om studenteverpleegkundiges voor te berei vir gemeenskapsgebaseerde verpleegkundige rolle en verantwoordelikhede.

Die doel van die navorsing was om riglyne daar te stel vir 'n gemeenskapsgebaseerde kurrikulum in psigiatriese verpleegkunde vir ' $n$ verpleegkollege in KwaZulu-Natal. 'n Kwalitatiewe, kwantitatiewe, verkennende, beskrywende en kontekstuele ontwerp is gevolg. Om die doelwitte van die studie te bereik, is ' $n$ situasionele analise in drie fases gedoen om die grondslag vir 'n gemeenskapsgebaseerde kurrikulum vir psigiatriese verpleegkunde te lê.

Fase I: 'n Dokument-analise van relevante regeringsbeleid en -wetgewing.

Fase 11: Statistiek van psigiatriese hospitale en gemeenskapspsigiatriese klinieke.

Fase III: Fokusgroep onderhoude met verpleegkundige opvoeders en ' $n$ literatuur kontrole en konseptuele raamwerk.

Die grondslag daargestel vanuit die drie fases is toegepas om riglyne daar te stel vir 'n gemeenskapsgebaseerde kurrikulum in psigiatriese verpleegkunde (Fase IV). Agt riglyne met praktise implikasies vir implemenering van ' $n$ gemeenskapsgebaseerde kurrikulum vir Psigiatriese Verpleegkunde is beskryt.

munity-based curriculum will play an important part in shaping the future of the nursing profession (Lowis, 1992:368). With regards to the psychiatric services, a systematic deinstitutionalisation of psychiatric inpatients is occurring and most are being sent home to families, relatives or hostels. Health care providers have already witnesses a drastic change in hospital admissions and length of stay, as well as the proliferation of community clinics 
and home care services. It is predicted that in future the vast majority of nurses will be working in community settings (Kuennen \& Moss, 1995:387)

According to Uys (1999:30) there are approximately 4500 psychiatric patient beds in institutions in KwaZulu-Natal, whilst approximately 55000 patients receive follow-up care in the community With most patients being in the community, it would be necessary for the psychiatric nursing science curriculum to be community-based. This is the reality of the situation in KwaZulu-Natal. The paradigm shift in psychiatric nursing science in KwaZulu-Natal is to provide a curriculum that meets the mental health needs and problems of the community.

Internationally, there also seems to be a nursing education curriculum revolution with a paradigm shift (Rentschler \& Spegman, 1996:389). The psychiatric nursing science curriculum needs to be community-based in order to be compatible with the new realities of the situation, that is most psychiatric patients are in the community and therefore the learning experiences of the student psychiatric nurses should be in communitybased settings (Bellack, 1998:99).

From the above introduction and problem statement the following research question applies, namely: What are the principles of mental health care to be included in the guidelines for a community-based curriculum in osychiatric nursing science for a nursing college in KwaZulu-Natal?

\section{Purpose Of Study}

The purpose of the study is to describe guidelines for a community-based curriculum in psychiatric nursing science for a nursing college in KwaZulu-Natal. The guidelines described in Phase IV, will be based on the principles obtained from Phases I, II and III. To reach this purpose, a situational analysis will be done to obtain the principles for a communitybased curriculum by:

- $\quad$ Conducting a document analysis of relevant government policies and legislation (Phase I).

- $\quad$ Collecting the statistics of psychiatric diagnoses of patients admitted to a psychiatric hospital admission unit and two community psychiatric clinics in the year 1996 (Phase II).

- $\quad$ Conducting focus group interviews with psychiatric nurse educators. From the findings of the focus group interviews, a literature control and conceptual framework were done (Phase III).
The principles of Phase I, II and III resulted in Phase IV, which forms the guidelines for a community-based curriculum in psychiatric nursing science for a nursing college in KwaZulu-Natal.

\section{Definition Of Central Concepts}

\section{Psychiatric nursing science}

Psychiatric nursing science is a human clinical health science based on a variety of theoretical frameworks with emphasis on the psychosocial and biophysical sciences. It constitutes knowledge regarding the promotion of mental health and the primary-, secondaryand tertiary prevention of mental illness (SANC, 1993:151) (Wilson \& Kneisl, 1996:32; Stuart \& Sundeen, 1995:8).

\section{Community-based curriculum}

A community-based curriculum is a means of achieving educational relevance to the community's health needs, in this instance, mental health needs of the community. It focuses on the health needs of individuals, families and groups in the community. It consists of an appropriate number of learning activities in a balanced variety of settings in the community, including rural and urban areas. The distribution of community-based learning activities throughout the duration of the curriculum is an essential characteristic of a community-based curriculum (WHO, 1987:8).

\section{Research Design}

It is a design using qualitative, quantitative, exploratory, descriptive and contextual strategies. The research was conducted in four phases. Phases I, III and IV were qualitative and Phase II was quantitative.

Phase I: Relevant government policies and legislation that influence mental health care

The data was collected from the following documents: The Reconstruction and Development Programme of the ANC, 1994; The National Health Plan of the ANC, 1994, The Mental Health Act 18 of 1973 as amended, The Health Act 63 of 1977 as amended, The National Qualifications Framework, and the South African Nursing Council's Regulation 425.

Data analysis constituted a document analysis to identify the principles that will be used for the guidelines for a community-based curriculum in psychiatric nursing science.

Phase II: Statistics from the psychiatric hospital admission unit and community psychiatric clinics

A non-probability sampling method was used where the first 100 patients' documents from an admission unit of a psychiatric hospital and the first 100 patients' documents from two community psychiatric clinics were used. Therefore a total of 300 patients' documents were used and 300 diagnoses were obtained. The sample was chosen according to a theoretical sampling principle (Polit \& Hungler, 1997:237).

The diagnoses were tabulated according to the categories of the Diagnostic and Statistical Manual of Mental Disorders (DSM IV). Once the date, namely the psychiatric diagnoses have been summarised in a frequency distribution, comparisons were made of the specific categories according to the DSM IV categories. The simple descriptive statistics used were percentages.

Phase III:Focus group interviews and literature control

Phase III was conducted in two parts, namely: In part 1, focus group interviews were conducted with psychiatric nurse educators. After the analysis of the data from the focus group interview, a literature control and conceptual framework were described.

The accessible population of psychiatric nurse educators $(n=6)$ was used for the focus group interviews. The eligibility criteria were that the psychiatric nurse educators have taught psychiatric nursing science over the last two years and were presently teaching the subject.

Focus group interviews (Krueger, 1994:06) were conducted with the psychiatric nurse educators. It was an agenda focus group with clear questions (Krueger, 1994:63). The curriculum process was used as framework for the questions during the focus group interviews and entailed their viewpoints of a community-based curriculum in psychiatric nursing science, the philosophy, the outcomes or ovirall objectives, the learning content, the learning experiences such as method, media, strategies, resources and assessment. The interviews were tape recorded and transcribed verbatim.

Data analysis was done according to the Huberman and Miles approach (in De Vos, 1998:340). The conceptual framework of the curriculum process was used as categories for the data analysis. To ensure trustworthiness, the researcher, as well as two external independent cod- 
ers, who are knowledgeable in qualitative research, analysed the transcriptions. A consensus discussion between the researcher and the two independ. ent coders took place. Consensus was reached between the researcher and the independent coders with regard to the conclusions from the data

A follow-up focus group interview was done which yielded no new information and the participants confirmed the findings as a true reflection of the focus group interviews.

From the findings of the focus group interviews, a literature control and conceptual framework were done (Part 2).

\section{Trustworthiness}

The methods of Lincoln and Guba (1985) were used to ensure trustworthiness of the researcher, methods of member checking, triangulation of data gathering (focus group interviews, two independent coders, literature control) and dense description were used to ensure trustworthiness

\section{Findings of Phase l: Relevant Government Policies and Legislation}

The following principles for a community based curriculum were identified from the policies and legislation:

- Mental health services are part of the National Health Plan. Mental health services are provided mainly by the community health services, district health services, provincial health services and the national health service. Students have to be allocated to these services.

- Fostering co-operation with traditional healers.

- Mental health care should not be regarded as a separate entity, but as part of a holistic approach to health care, and should aim to integrate mental health care into all other health sectors, especially at primary health care level.

- Families and caregivers of mentally ill persons at home, need support on how to manage the mentally ill person at home.

- The role of non-governmental organisations as community-based organisations providing mental health services, needs to be acknowledged.

- Facilities to provide services for violence prevention, drug- and alcohol abuse, youth groups, parent groups, survivors of rape and child abuse, need to be supported.

- Nurses in psychiatric services, working in the community, must be culturally sensitive.
- Referral to appropriate agency by the nurse of cases, such as substance abuse.

- Nurses need to know how to counsel and support victims of violence.

- Community care, rehabilitation and education of the mentally disabled needs to be improved.

- Skills of psychiatric nurses caring for people in the community settings, need to be developed, specifically to handle situations related to community care of psychiatric patients.

- Since more psychiatric patients are in the community, the psychiatric student nurses' clinical placement should be 50 percent in the community.

- Respect for human rights of mentally ill persons.

- The curriculum, which is a learning programme, must give attention to critical outcomes.

- The qualification in psychiatric nursing science must conform to the national qualification criteria of meeting the mental health needs and problems of the community.

- The provisions of the SANC, Regulation 425 must be abided by, such as philosophy of the SANC.

- The psychiatric student nurse must apply principles inherent to the scientific approach to nursing in the management of patient care, that is the nursing process.

- The subject content of a communitybased curriculum in psychiatric nursing science must cover aetiology, pathology, clinical presentation, diagnostic investigation, diagnosis, prevention, treatment, prognosis and rehabilitation with regard to the most prevalent psychiatric conditions in various clinical areas of practice.

- Clinical accompaniment of students by psychiatric nurse tutors is now compulsory. A preceptorship system will enhance students' clinical skills.

- Skills that students should be competent in before their practical placements are communication skills, group skills, counseling skills, crisis intervention skills and stress management skills. These are done by simulations and role-plays in the classroom.

- Emphasis must be placed on the promotion of mental health and the prevention of mental illness.

\section{Findings Of Phase li: Stotistics from the Psychiatric Hospital Admission Unit and}

\section{Community Psychiatric}

\section{Clinics}

Table 1 reflects the data of this phase of the research.

Statistics of psychiatric diagnoses reveal mental health needs and problems in the order of prevalence in the community. The psychiatric diagnoses, in order of prevalence are Schizophrenia, and other psychotic disorders; mood disorders, especially depression; disorders of infancy, childhood and adolescence; substance related disorders; anxiety disorders; delirium, dementia and other amnestic disorders; personality disorders; somatoform disorders and lastly malingering.

\section{Findings Of Phase lii: Findings of Focus Group Interviews and Literature Control and Conceptual Fromework}

Based on the agenda of the focus groups the following categories were identified, namely

- Community-based curriculum

- Philosophy

- Outcome-based curriculum

- Learning content

- Learning experience

- Assessment or evaluation

The conceptual framework for the study is described in figure 1.

The following are the salient points or principles for a community-based curriculum for psychiatric nursing science from Phase III of the research.

\section{Community-based curriculum}

A community-based curriculum focuses on educating student psychiatric nurses to meet the mental health needs and problems of the community (WHO, 1987:8). A community is within a hospital and outside the hospital. A community is made up of people who interact by sharing their political-, social-, economic-, cultural- and mental health interests and aspirations. An assessment of the community's mental health needs and problems starts with assessment of individuals and families who make up the community. Research should be done in the form of statistics of psychiatric diagnoses at psychiatric hospitals and clinics in order to establish the prevalence of mental conditions, which in turn will reveal the mental health needs and problems. Community involvement is 
Table 1: Statistics Of Diagnosis

(Adapted From Diagnostic And Styatistical Manual Of Mental Disorders-fourth Edition) AND Kaplan \& Sadock (1994 : 309)

\begin{tabular}{|c|c|c|c|}
\hline DIAGNOSTIC CATERGORY & TOTAL NUMBERS & $\begin{array}{l}\text { TOTAL OF THE } \\
\text { ROW }\end{array}$ & PERCENTAGE \\
\hline $\begin{array}{l}\text { Disorders usually diagnosed in in- } \\
\text { fancy, } \\
\text { Childhood or adolesence } \\
\text {-MENTAL RETARDATION } \\
\text {-ATTENTION DEFICIT AND } \\
\text { BEHAVIOUR DISORDER }\end{array}$ & $\begin{array}{l}39 \\
10\end{array}$ & 49 & $16,33 \%$ \\
\hline $\begin{array}{l}\text { Delirium, Dementia and Amnesia } \\
\text { and other Cognitive Disorders } \\
\text {-DEMENTIA }\end{array}$ & 14 & & $4,60 \%$ \\
\hline $\begin{array}{l}\text { Substance Related Disorders } \\
\text {-ALOCOHOL RELATED DISORDERS } \\
\text {-AMPHETAMINE RELATED DISOR- } \\
\text { DERS } \\
\text {-CANNABIS RELATED DISORDERS } \\
\text {-POLYSUBSTANCE RELATED DIS- } \\
\text { ORDERS }\end{array}$ & $\begin{array}{l}8 \\
3 \\
\\
6 \\
13\end{array}$ & 30 & $10,33 \%$ \\
\hline $\begin{array}{l}\text { Schizophrenia and other Psychotic } \\
\text { Disorders } \\
\text {-SCHIZOPHRENIA } \\
\text {-SCHIZOPHRENIFORM DISORDER } \\
\text {-SCHIZO AFFECTIVE DISORDER } \\
\text {-DELUSIONAL DISORDER } \\
\text {-BRIEF PSYCHOTIC DISORDER }\end{array}$ & $\begin{array}{l}54 \\
8 \\
9 \\
7 \\
8\end{array}$ & 86 & $28,60 \%$ \\
\hline $\begin{array}{l}\text { Mood Disorders } \\
\text {-DEPRESSIVE DISORDERS } \\
\text {-BIPOLAR DISORDERS }\end{array}$ & $\begin{array}{l}63 \\
19\end{array}$ & 82 & $27,33 \%$ \\
\hline $\begin{array}{l}\text { Anxiety Disorders } \\
\text {-PANIC DISORDER } \\
\text {-SOCIAL PHOBIA } \\
\text {-OBSESSIVE COMPULSIVE DISOR- } \\
\text { DER } \\
\text {-POST TRAUMATIC STRESS DIS- } \\
\text { ORDER }\end{array}$ & $\begin{array}{l}8 \\
2 \\
5 \\
\\
8\end{array}$ & 23 & $7,6 \%$ \\
\hline $\begin{array}{l}\text { Somatoform Disorder } \\
\text {-CONVERSION DISORDER }\end{array}$ & 2 & & $0,6 \%$ \\
\hline $\begin{array}{l}\text { Personality Disorders } \\
\text {-ANTI-SOCIAL PERSONALITY DIS- } \\
\text { ORDER } \\
\text {-BORDERLINE PERSONALITY DIS- } \\
\text { ORDER } \\
\text {-HISTRIONIC PERSONALITY DIS- } \\
\text { ORDER }\end{array}$ & $\begin{array}{l}2 \\
3 \\
1\end{array}$ & 6 & $2 \%$ \\
\hline $\begin{array}{l}\text { Additional conditions that may be } \\
\text { the focus of clinical attention } \\
\text {-MALINGERING }\end{array}$ & 8 & & $2,6 \%$ \\
\hline TOTAL & 300 & & $99,99 \%$ \\
\hline
\end{tabular}




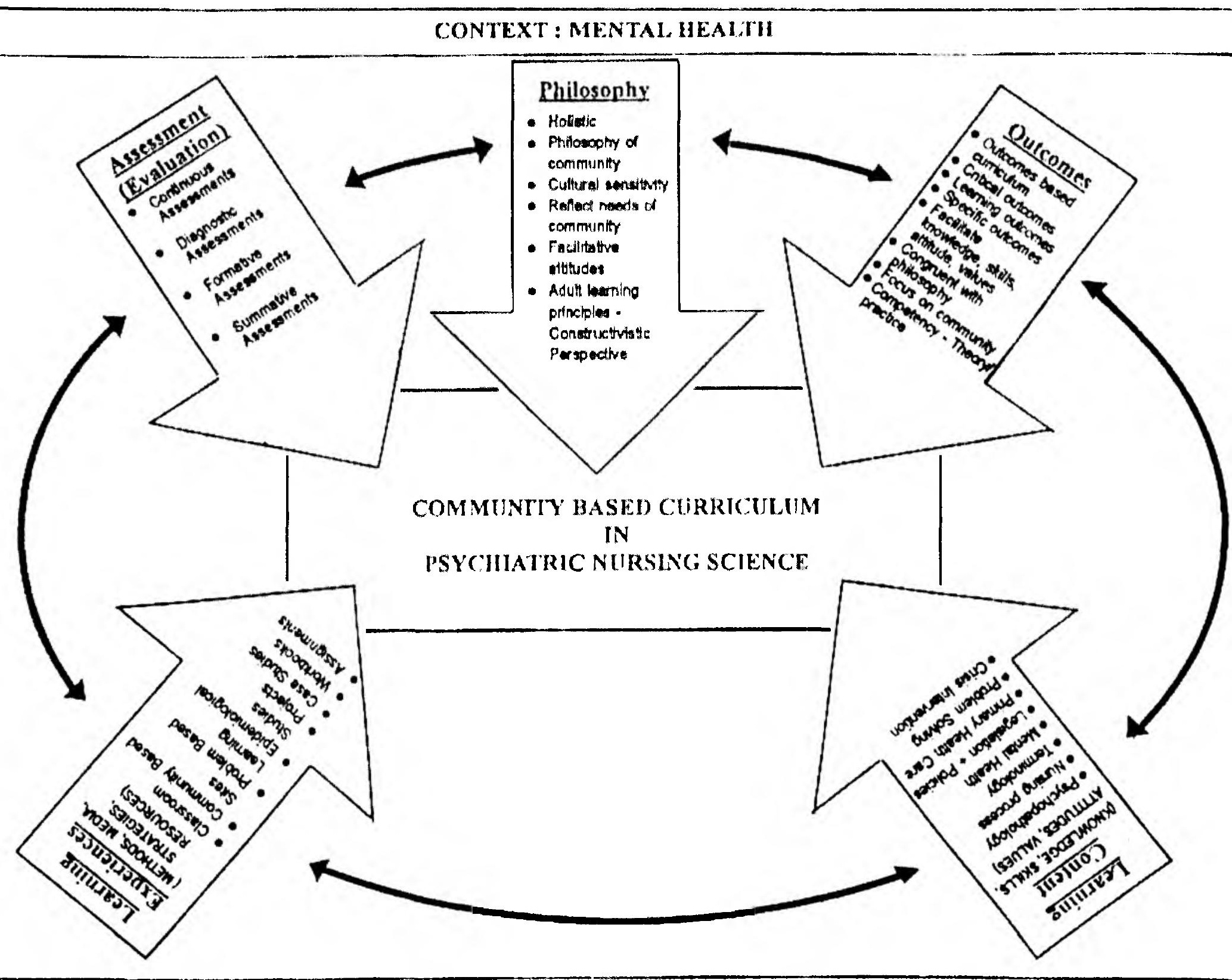

CONTEXT : MENTAL HEAITTH

URF, I CONCEPTUAL, MODEL, FOR A COMMINTTY BASED CURRICULUM IN PSYCHIATRIC NURSING SCTE 
necessary for the success of the curriculum because the community can participate in epidemiological studies for identifying mental health needs and problems and assist in the practical aspects. Close collaboration is needed with leaders, community representatives or community members. The nurse educator should develop a relationship of trust with the community. Negotiation skills are very important for community entry and involvement. Informing the community psychiatric nurse, governmental departments and non-governmental departments and voluntary groups in the community about the psychiatric nursing curriculum. Requesting their assistance and involvement for community entry and practical aspects. Community involvement is enhanced if there is positive visible influence by the student psychiatric nurse in the mental health care of the community. Clinical accompaniment by the psychiatric tutors, who can give guidance to students on how to handle patients with problems (Mellish, 1998:100).

Continuity of community involvement can be ensured by the community psychiatric clinic staff, incoming new students or continuing with the planned programmes. The community psychiatric nurse is the key person for entry into the community mental health arena. The student psychiatric nurse must be culturally sensitive to the community's values, beliefs and practices in order to obtain and maintain community participation (Snadden \& Mowat, 1995:298).

\section{Philosophy}

The philosophy is the first stage of the community-based curriculum process. The philosophy should be holistic and it should incorporate the philosophy of the South African Nursing Council. The philosophy of the nursing college that will be conducting the curriculum must be included. The philosophy should be sensitive to the philosophy of the community it is to serve. The attitude of nurses should be facilitative, that is helpful, caring and apply advocacy towards the mentally ill. They should embrace the adult learning principles. The philosophy should have a constructivistic philosophical perspective where the learner experiences deep-holistic life-long learning, and is an active constructor of her own knowledge. This learning brings about a conceptual change (Mashaba \& Brink, 1994:7). The philosophy should reflect the mental health needs and problems of the community.

\section{Outcomes-based curriculum}

The community-based curriculum in psychiatric nursing science should be an outcomes-based curriculum in keeping with requirements of the South African Qualifications Authority. Emphasis is on what the student knows and can do at the end of the learning programme. Attention needs to be given to critical outcomes as this is mandatory. Learning outcomes are the results of the learning process and refer to knowledge, skills, attitudes and values the student is expected to acquire in a given learning area.

Specific outcomes are essential and re fer to knowledge and understanding and should be displayed in the particular context of psychiatric nursing science. The outcomes-based curriculum must be congruent with the philosophy of the community, that is their culture, values, beliefs, the philosophy of the Nursing Council, the nursing college, the discipline of psychiatric nursing science and the nurse's own philosophy. The outcomes-based curriculum should focus more on community-based care than institutional care. The outcomes-based curriculum must have a competencybased approach, whereby there will be competence in theory and practice.

\section{Learning content}

The learning content should be on the knowledge, skills, attitudes and values required for a community-based curriculum in psychiatric nursing science. The SANC Regulation 425 requirements for subject content in psychiatric nursing science is mandatory to be included, that is the aetiology, pathology, clinical presentation, diagnostic investigations, diagnosis, prevention, treatment, prognosis and rehabilitation of prevalent psychiatric conditions. The learning content must be outcomes-based in keeping with the outcomes based curriculum. The learning content is important but not over-emphasised. The learning content should include knowledge, skills, attitudes and values in the: Nursing process, psychopathology, terminology, mental health, mental health legislation and policies, primary health care aspects, problem solving and crisis intervention (Klopper, 1994:16)

\section{Learning experiences}

Learning experiences are in the classroom and at the community-based sites. Learning experiences assist students to meet specific outcomes. Teaching strategies are a broad plan of action to achieve learning outcomes. The deductive strategy is important where students' active participation is required. Co-operative learning strategy is used where group work is essential.
Problem-based learning is where a student utilises a problem as a stimulus to discover a solution. Facilitation on behalf of the nurse educator makes it easier for students to participate.

Mentoring provides educational and personal support to the student throughout the period of practical placement. Preceptorship of students enhances their learning in clinical settings.

Lectures, simulations, role-plays and videos are used in the classroom. Epidemiological studies are important to identify mental health problems. Case studies are important for developing psychiatric nursing skills in assessment and planning of care for specific patients.

Workbooks, projects and assignments are valuable when students are allocated to community-based practical sites. Resources are the communitybased sites such as the community psychiatric clinics, patients' homes, work places, sheltered workshops, governmental organisations, non-governmental organisations, such as mental health societies, voluntary organisations, such as Life Line and self-help groups, such as Alcoholic Anonymous.

\section{Fissessment (evaluation)}

Assessment will be by means of continuous assessments. Assessment will be done regarding psychiatric knowledge, skills, attitudes and values. Theoretical assessment will be done in the class and practical assessments at communitybased sites.

Assessment will be of the specific outcomes. Assessment will be of diagnostic assessments, formative assessments and summative assessments. Assessments will be made of pre-tests, standardised tests, questionnaires, observations, discussions, readings, checking, questions and answers, assignments, portfolio assessments, clinical performances, interviews, examinations projects, student feedback, simulations, case studies, research, essays, debates and demonstrations.

\section{Conclusion and Guidelines}

The findings of Phases I, II and III resulted in Phase IV, which constitutes the guidelines for a community-based curriculum in psychiatric nursing science.

\section{Guideline 1}

A community-based curriculum should reflect the mental health needs and problems of the community. 
Operationalisation

To operationalise this guideline, the following action should be implemented:

- A Community Based Curriculum should be built on a situational analysis where the central focus should be on the mental health needs and problems of the community.

This can be achieved by:

- Analysis of statistics from community psychiatric clinics and psychiatric hospitals.

- Community involvement in identification of mental health needs and problems (Phase III).

- Creating a sensitivity during nursing education for the mental health needs and problems of the community with the student psychiatric nurses.

\section{Guideline 2}

The philosophy of a community-based curriculum in psychiatric nursing science must be made up of various other relevant philosophies (holistic).

\section{Operationalisation}

To operationalise this guideline the following action should be implemented:

- The philosophy should be similar to the South African Nursing Council's philosophy as stated in Regulation 425.

- The philosophy must also be similar to that of the nursing college which conducts the curriculum.

- There must be sensitivity to the philosophy of the community the nurse is to serve.

- The nurse's attitude should reflect facilitation, that is one of caring, helpfulness and advocacy.

- The philosophy should embrace the adult learning principles, ensuring active constructivistic, deep-holistic, life-long learning.

- The philosophy should reflect the mental health needs and problems of the community.

\section{Guideline 3}

The community-based curriculum in psychiatric nursing science should be an outcomes-based curriculum.

Operationalisation

To operationalise this guideline, the following action should be implemented:

The community-based curriculum must be an outcomes-based curriculum. This can be achieved by:

- Following the guidelines of the national qualification framework of the South Af- rican Qualifications Authority.

- Forming critical outcomes and unit standards in psychiatric nursing science are mandatory.

- Forming learning outcomes in knowledge, skills, attitudes and values in psychiatric nursing science.

- Forming specific outcomes in psychiatric nursing science.

- The outcomes must be congruent with philosophy of the community, the South African Nursing Council and the nursing college where the curriculum is to be implemented.

- Focus will be more on communitybased care rather than institutional care.

- A competency-based approach will be used to ensure competency in theory and practice.

\section{Guideline 4}

The learning content of a communitybased curriculum in psychiatric nursing science should impart knowledge, skills, attitudes and values regarding menta health care.

\section{Operationalisation}

To operationalise this guideline, the following should be implemented:

- Specific knowledge and skills in the learning content should include:

- The nursing process in psychiatric nursing science is assessment, planning, implementation and evaluation of mental health needs and problems

- Legislation, such as the Mental Health Act 18 of 1973 as amended and Health Act 63 of 1977 as amended.

- The provisions of the South African Nursing Council Regulation 425 regarding theoretical and practical aspects.

- DSM IV criteria for diagnosing and categorising mental illness must be used.

- Knowledge on prevalent mental disorders in the community such as Schizophrenia, mood disorders, disorders of infancy, childhood and adolescence, substance related disorders, like alcohol and drugs, anxiety disorders, delirium, dementia and amnestic and other cognitive disorders, malingering, personality disorders and somatoform disorders.

- The aetiology, pathology, clinical presentation, diagnostic investigation, diagnosis, prevention, treatment, prognosis, rehabilitation of mental health needs and problems.

- Relevant psychiatric terminology.

- Mental health especially the primary, secondary- and tertiary prevention of mental illness.
- Primary health care aspects of mental health care, such as accessibility of services.

- The handling of patients and family in community settings.

- Psychological support to victims of violence, abusers of drugs and alcohol, survivors of rape, child abuse victims, youth- and parent groups.

- Competency in skills before placement in practical areas include communication skills, group skills, counseling skills, crisis intervention skills, stress management skills, negotiation skills and problem solving skills.

- Epidemiological surveys to obtain statistics that reveal the prevalence of mental disorders obtained at community psychiatric clinics and psychiatric hospitals.

- Community involvement and participation is vital for the success of a community-based curriculum in psychiatric nursing science.

- Collaboration with leaders, representatives and members in identifying mental health needs and problems.

- Developing trusting relationships with members of the community is essential.

The attitudes and values in the learning content must be inculcated in students from the beginning of the learning programme

- Emphasis should be placed on multicultural aspects of the community.

- For the psychiatric student nurses to be culturally sensitive to the people of the community they are serving.

- To respect the human rights of the mentally ill.

\section{Guideline 5}

The methods, media, strategies and resources used during the communitybased curriculum should enhance learning of knowledge, skills, attitudes and values of mental health care.

\section{Operationalisation}

To operationalise this guideline, the following action should be implemented in a community-based curriculum:

- The methods, media, strategies and resources used must be compatible with adult education principles in a tertiary educational setting.

This can be achieved by:

- Utilising adult learning principles, which is active learning, deep-holistic life-long learning, and constructivistic learning. 
- An outcomes-based approach should be used according to the new South African Qualifications Authority requirements.

- A competency-based approach with competence in theoretical and practical aspects

- A problem-based learning approach which is a method preferred by adult students.

- Lectures, simulations, role-plays and videos to be used in classrooms.

- Exposure in clinical settings such as in community clinics, psychiatric hospitals and other selected communitybased sites.

- Clinical accompaniment by tutors to enhance theoretical and practical correlation

- Mentoring of students by the nurse educator to empower and enable students.

- Preceptorship supervision of students in clinical areas is required.

- Inductive strategy is where students have to discover information by themselves.

- Deductive strategy is used when a general principle is used in specific cases.

- Co-operative strategy is where group work is essential for learning.

- Facilitation where the tutor makes it easier for students to participate in otherwise difficult events

- Epidemiological studies are essential for students to identify mental health needs and problems in the community.

- Case studies of specific cases is an important learning activity.

- Workbooks must be used throughout their clinical placements to enhance learning.

- Projects can be given for individuals or groups of students in mental healthrelated aspects.

- Assignments for completion at various stages of the learning programme is essential.

\section{Guideline 6}

The allocation of student psychiatric nurses' learning experiences should enhance their knowledge, skills, attitudes and values in mental health care. This will take place in the classroom and community settings.

Operationalisation

To operationalise this guideline, the following action should be implemented:

- In college classrooms there should be mainly interactive lectures, simulations, role-plays, and videos.

- Clinical allocation during the learning programme should be in communitybased settings maximally and psychiatric hospital wards minimally so that students gain more exposure to patients in the community than those in the psychiatric hospital.

- Allocation to various levels of governmental health services, such as community health services, community psychiatric services, district health services, provincial health services and national health services

- Allocation to non-governmental organisations, such as mental health societies who perform many services such as maintaining of hostels, sheltered workshops for mentally ill persons in the community.

- There should also be clinical allocation of students to services for violence prevention, drug- and alcohol abuse youth groups, parent groups, survivors of rape, and child abuse.

- Home visits to patients where they live or work in order to support them and assist families and caregivers in the managing of the psychiatric patient at home.

\section{Guideline 7}

There should be community involvement in a community-based curriculum.

\section{Operationalisation}

To operationalise this guideline, the following action should be implemented:

- The students should practice negotiation skills before entering the community.

- Sensitivity to the community's cultural beliefs, values and practices must be learnt.

- Collaboration with community leaders, representatives and members should be sought.

- Nurse educators must develop a relationship of trust with the community.

- They should inform other government departments, non-governmental organisations and voluntary organisations about the community-based curriculum and enlist their participation in practical aspects

- They should enlist the community's involvement in epidemiological studies to identify mental health needs and problems and assist in practical aspects.

- Community participation is enhanced if there is positive, visible influence, such as stress management groups, youth groups, anti-alcohol and drug groups, etc.
- Clinical accompaniment of students by tutors enhances the professional skills attained by the students, especially in handling mental health problems in the community.

- Continuity of community involvement can be maintained by informing the community psychiatric nurses and incoming new students about the programmes that were commenced and for their continuity.

- The community psychiatric nurse is the key person in order to enter the community mental health arena and her involvement in all spheres of the curriculum is crucial.

\section{Guideline 8}

Assessment (evaluation) in a community-based curriculum in psychiatric nursing science is compulsory to check whether the outcomes in knowledge skills, attitudes and values have been achieved.

\section{Operationalisation}

To operationalise this guideline, the following should be implemented:

- Assessment (evaluations) will be continuous throughout the learning programme.

- Assessment will be on mental health knowledge, skills, attitudes and values.

- Theoretical assessment will be done in the class and practical assessments in the community settings where students are allocated to

- Assessment will be on specific outcomes.

- Assessment will be in the form of di agnostic assessments, formative as sessments, and summative assessments.

- The above-mentioned assessments (evaluations) will be achieved by conducting pre-tests; standardised tests questionnaires; observations; discussions; readings; checking; questions answers; readings; assignments; portfolio assessments; clinical performances; interviews; examinations projects; student feedback; simulations case studies; research; essays; debates and demonstrations.

\section{Recommendations}

The recommendations from this study will be discussed under three categories.

\section{Further research}

This research was conducted in a region of KwaZulu-Natal. Further study in this 
field with respect to other provinces is needed so that the information is transferable. Further work is needed in order to use these guidelines to develop standards for evaluation of a communitybased curriculum.

\section{Nursing education}

The guidelines must be implemented in psychiatric nursing science.

\section{Nursing practice}

It is important to update statistics of patients' profiles. One should create sensitivity to different cultural beliefs, values and practices in psychiatric nurses. There should be empowerment of the community regarding mental health promotion and prevention of mental illness. There should be networking with other agencies to promote mental health and prevent mental illness and management of mental illness in the community. There should be capacity building. There should always be community involvement in the form of identifying mental health needs and assistance in practical aspects. There should be respect for the human rights of the psychiatric patients. 


\section{Bibliography}

AFRICAN NATIONAL CONGRESS. 1994(a). The Reconstruction and Development Programme. Johannesburg: Umanyane Publications.

AFRICAN NATIONAL CONGRESS. 1994(b). A National Health Facilities Plan for South Africa. Maseru: Bahr Mapping and Printing.

AMERICAN PSYCHIATRIC ASSOCIATION. 1994. Diagnostic and statistical manual of mental disorders. Fourth Edition. USA: WB Saunders Co.

BELLACK, J.P 1998. Community-based nursing practice: necessary, but not sufficient. Journal of Nursing Education, 37(3), March 1998.

BURNS, N. \& GROVE, S.K. 1993. The practice of nursing research. USA: Mosby.

DE VOS, A.S. 1998. Research at grassroots. Pretoria: JL Van Schaik Publishers.

KAPLAN, H.I., SADOCK, B.J., \& GREBB, J.A. 1994. Synopsis of psychiatry. USA: Williams \& Wilkins.

KLOPPER, H.C. 1994. A Constructivistric Perspective of Learning in Nursing Science. Johannesburg: Rand Afrikaans University.

KRUEGER, PA. 1994. Focus groups. London: Sage Publications.

KUENNEN, J. \& MOSS, V.A. 1995. Community program planning: A clinical outcome. Journal of Nursing Education, 34( 8).

LINCOLN, Y.S. \& GUBA, E.G. 1985. Naturalistic inquiry. California: Sage.

LOWIS, A. 1992. Moving to a community-based curriculum. Occupational Health, December 1992.

MASHABA, T.G. \& BRINK, H.I.L. 1994. Nursing Education: an International Perspective. Cape Town: Juta.

MELLISH, J.M., BRINK, H.I.L., \& PATON, F. 1998. Teaching and Learning the Practice of Nursing. Durban: Butterworth

POLIT, D.F., \& HUNGLER, B.P. 1997. Essentials of nursing research: methods, appraisal and utilisation. USA: JB Lippincot Company.

RENTSCHLER, D.D., \& SPEGMAN, A.M. 1996.Curriculum revolution: Realities of change. Journal of Nursing Education, 35 (9): 368 .

SNADDEN, D., \& MOWAT, D. 1995. Community Based Curriculum Development: what does it really mean? Medical Teacher. 17. (3), $297 \cdot 306$.

STUART, W.G., \& SUNDEEN, S.J. 1995.: Principles and practice of psychiatric nursing. USA: Mosby.

SOUTH AFRICAN NURSING COUNCIL. 1985. Regulation No 425. Pretoria: South African Nursing Council.

SOUTH AFRICA (REPUBLIC). ACTS, STATUTES, ETC. Mental Health Act, 1973 (Act No 18 of 1973). Pretoria: Government Printers.

SOUTH AFRICA (REPUBLIC). ACTS, STATUTES, ETC. Health Act, 1977 (Act No 63 of 1977). Pretoria: Government Printers. SOUTH AFRICAN QUALIFICATIONS AUTHORITY. 1995. The national qualification framework. Johannesburg: Heinemann. SOUTH AFRICAN QUALIFICATIONS AUTHORITY. SAQA Bulletin, 1997. Vol. 1, No 1 May/June 1997.

UYS, L.R. Community-based psychiatric nursing education. DENOSA Nursing Update, 1999: 23 (2):30. WILSON, H.S., \& KNEISL, C.R. 1996. Psychiatric nursing. USA: Addison - Wesley.

WORLD HEALTH ORGANISATION, (GENEVA). 1987. Study group on community-based education of health personpeil.C.Geneva: World Health Organisation. 